\title{
MISCONCEPTION PROFILE OF HIGH SCHOOL STUDENT ON ELECTROLYTE AND NON-ELECTROLYTE SOLUTION USING PICTORIAL-BASED TWO-TIER MULTIPLE CHOICES DIAGNOSTIC TEST
}

\author{
$\underline{\text { Nahadi }}^{\star}$, Wiwi Siswaningsih, and Hanifah Kurnia M \\ Department of Chemistry Education, Faculty of Mathematics and Natural Science Education, \\ University of Indonesian Education \\ Dr. Setiabudhi Street No. 229, Isola, Sukasari, Bandung City, West Java 40154, Indonesia \\ * Correspondence: phone/Fax (022) 2001108,Email: nahadi@upi.edu
}

$\begin{array}{lll}\text { Received: December 16, } 2020 & \text { Accepted: December 24, } 2020 \quad \text { Online Published: December 31, } 2020 \\ \text { DOI : 10.20961/jkpk.v5i3.46739 }\end{array}$

\begin{abstract}
The study had purpose to determine misconceptions profile of class $X$ high school students in Kuningan on electrolyte and non-electrolyte solutions using descriptive methods. The instrument used was a pictorial-based two-tier multiple choices diagnostic test consisted 18 questions. The instrument had CVR and CVI values was one, and Cronbach's Alpha value for a whole item was 0,706 . The items were applied to class $X$ students in schools with high, medium and low category. Based on results of application, the most common students' misconceptions on electrolyte and non-electrolyte solutions, when dissolved in water, ionic compounds would be ionized into ions, oxygen atom in water molecule interacted with anions and hydrogen atoms in water molecule interacted with cations (37.78\%). The students' misconceptions in high and low category schools had a significant difference. Based on the one-way ANAVA test, the significance level $<0.05$, there was 0.045 . The students' misconception based on gender did not have a significant difference. Based on results of $t$ test, the significance level $>0.05$, there was 0.755 .
\end{abstract}

Keywords: Electrolyte and non-electrolyte solutions, misconceptions, profile, pictorial-based twotier multiple choices diagnostic tests.

\section{INTRODUCTION}

Assessment was the process of gathering and processing information in order to make decisions [1]. One of the functions of assessment was to identify student misconceptions. Misconceptions were students' conceptions that were built from their daily experiences that were not suitable with scientific concepts [2]. Identification of student misconceptions could be done in several ways, there were concept maps, interviews and two-tier multiple choices diagnostic tests [3]. In addition, a test using a sub-microscopic diagram was used [4]. According to Peterson, Treagust and Kabapinar, one of the most often used techniques to identify misconceptions was a two-tier multiple choices diagnostic test because it could assess large numbers of samples at one time, so that it more efficient [3]. Besides that, diagnostic tests could provide an accurate overview of the students' misconceptions based on the error information [5]. The two-tier diagnostic 
test was an instrument that can identify student misconceptions [6]. The two-tier diagnostic test was developed with the first tier contains the answer option and the second tier contains the reasons based on the first tier [7]. The advantages of a two-tier diagnostic test were to minimize the guess's answers and more practical to use for students and teachers $[8,9]$.

Previous research had shown the effectiveness of two-tier multiple-choice diagnostic tests in identifying misconceptions in chemistry. Tan proved that a two-tier multiple-choice diagnostic test can identify student misconceptions on the ionizing energy concept [10]. Other than that, on the chemical reaction, separation, electrochemistry, and chemical bonds $[11,8,12,13,14]$.

The narrative question had a weakness that can make students tire to understand the core problems in the matter [15]. To overcome these weaknesses, the researcher could use pictorial. The pictorial such as pictures, columns, tables, diagrams, graphs, and mind maps can make it easier to understand [16]. Besides, the images could represent the sub-microscopic level [17]. The pictorial can also identify student misconceptions [18]. The study related with this study was developed pictorial-based two-tier multiple choice diagnostic test, on electrolyte and non-electrolytes solutions by Wiwi, Firman and Rofifah [19].

Electrolyte and non-electrolyte solutions were one of the prerequisite concepts for understanding the next concept, there were acid-base, hydrolysis, buffer solutions, solubility and solubility product, colligative properties of solution and electrochemistry.
These concepts involved a lot of reactions between ions in solution. The reactions of the ions in solution required students' understanding at the sub-microscopic level. Many researches stated that students had misconception at sub-microscopic level. The concepts in chemistry were interrelated, so that if the prerequisite concept that students had is wrong, then the next concept would be wrong [11]. Therefore, research about misconceptions on electrolyte and nonelectrolyte solution was important to do.

Research about development of a pictorial-based two-tier multiple choices diagnostic test on electrolyte and non-electrolyte solution had been done by Wiwi, Firman and Rofifah. The result of research was produced 18 valid and reliable items. The test developed included 9 concepts in electrolyte and non-electrolyte solution, there were solvents, solutes, electrolytes, types of chemical bonds of electrolyte compounds, dissociation of ionic compounds, ionization of covalent compounds, the conductivity of ionic compounds and electrical conductivity of electrolytes and non-electrolytes. Besides, several misconceptions were identified, there were: electrolytes were substances that could conduct electric current; electrolyte solutions could conduct electric current because they contain free electrons; all electrolytes were ionic compounds [19].

A pictorial-based two-tier multiple choices diagnostic test on electrolyte and non-electrolyte solution developed by Wiwi, Firman and Rofifah was only tested limited to a number of students in one school in Bandung, so the misconceptions revealed could not be generalized. Therefore, further 
research was needed to apply two-tier multiple choices diagnostic test more broadly and deeply in order to obtain a more varied profile of student misconceptions on electrolyte and non-electrolyte solution.

In this research, analysis of misconceptions was carried out for all samples, then analysis the differences of student misconceptions in high, medium and low category schools was carried out because based on the results of Rahmawati's research, students at three schools with different levels had different misconceptions [20]. In addition, analysis the differences of student misconceptions based on gender because, according to Devetak, women had a lower ability to read and describe the sub-microscopic level of a chemical concept [21]. Based on the students 'misconceptions on electrolyte and non-electrolyte solution that was revealed, it could be mapped with variations, so that the profile of students' misconceptions on electrolyte and non-electrolyte solutions could be known.

\section{METHODS}

This study used a descriptive quantitative method. Participants were class $X$ high school students in high, medium and low category school in Kuningan who had studied electrolyte and non-electrolyte solutions. Three classes were selected as participants from each school.

The instrument used was a pictorialbased two-tier multiple choices diagnostic test on electrolyte and non-electrolyte solution that had been developed by previous researchers, which consisted of 18 pictorialbased two-tier multiple choices questions.
The instrument used had been tested for its feasibility with the CVR and CVI value was one and the reliability value (Cronbach's Alpha) for the whole item is 0.706 [19].

This study was carried out in three major stages, there were preparation stage, implementation stage and data analysis stage. In the preparation stage of this research, questions from pictorial-based twotier multiple choices which had been developed by Wiwi, Firman and Rofifah and had been valid analyzed by experts (teachers), then made revisions. In addition, in this preparation stage, selected three school that would be the sample for this research.

At the implementation stage, a pictorial-based two-tier multiple choices diagnostic test was carried out for a number $X$ class high school students who had studied electrolyte and non-electrolyte solution in high, medium and low categories schools in Kuningan.

At the data analysis stage, the percentage of each response was calculated, as followed:

$P V C=\frac{\mathrm{x}}{\mathrm{N}} \times 100 \%$

Note:

$\mathrm{PVC}=\%$ percent value criteria

$\mathrm{N}=$ total number of students

$\mathrm{X}=$ number of students who answered item

Students' answers were categorized by their level of understanding. The following was a categorization of students' understanding based on the answers of pictorialbased two-tier multiple choices [22]. 
Table 1. Categorization of students' understanding

\begin{tabular}{|c|c|c|}
\hline \multicolumn{2}{|c|}{ Student's Answer } & \multirow{2}{*}{ Category } \\
\hline Tier 1 & Tier 2 & \\
\hline Correct & Correct & Understanding \\
\hline Correct & Wrong & Misconseption \\
\hline Wrong & Correct & Misconception \\
\hline Correct & Unanswered & $\begin{array}{l}\text { Partial } \\
\text { Understanding }\end{array}$ \\
\hline Unanswered & Correct & $\begin{array}{l}\text { Partial } \\
\text { Understanding }\end{array}$ \\
\hline Wrong & Wrong & Misconception \\
\hline Wrong & Unanswered & No Understanding \\
\hline Unanswered & Wrong & No Understanding \\
\hline Unanswered & Unanswered & No Understanding \\
\hline
\end{tabular}

To find out the misconceptions of students on electrolyte and non-electrolyte solutions according to Peterson could be done by determining significant misconceptions. The misconception was said to be significant if it was found at least $>10 \%$ of total student sample, then selected the response that had the largest percentage [10].

Furthermore, to find out the difference between student misconceptions in three schools and misconceptions between male and female students, it could be done by hypothesis testing. Before testing the hypothesis, the normality and homogeneity tests were carried out. The normality test could be done with the Kolmogorov-Smirnov or Shapiro-Wilk test. The normality and homogeneity tests were carried out by the Lavence Test. The hypothesis test used was the One-Way ANOVA test. All tests could use SPSS Version 20 for Windows.

To find out which schools had significant differences misconceptions, a Post Hoc Test could be carried out using SPSS Version 20 for Windows. Furthermore, to find out the difference misconceptions between male and female students, the test (independent sample t-test) could be used. The $t$ test could be performed using SPSS Version 20 for Windows.

Furthermore, an analysis of differences student's misconceptions for each concept was carried out. Analysis of differences student's misconceptions for each concept could be done by categorizing the difference percentage of total misconceptions.

Table 2. Categorizing the Difference Percentage of Total Misconceptions for Each Concept

\begin{tabular}{cc}
\hline $\begin{array}{c}\text { Difference } \\
\text { Percentage (\%) }\end{array}$ & $\begin{array}{c}\text { Interpretation Criteria for } \\
\text { Percentage Difference }\end{array}$ \\
\hline$<0,99$ & No different \\
$1-18,99$ & Slightly different \\
$19-36,99$ & Different \\
$37-54,99$ & Very different \\
\hline
\end{tabular}

\section{RESULT AND DISCUSSION}

The misconceptions of class $X$ high school students in Kuningan on electrolyte and non-electrolyte solutions which were significant with the largest percentage, there were: the solvent was a solution component whose amount was always more than the solute $(31.43 \%)$; the solute was a solution component whose amount was always less than the solvent (24.44\%); electrolytes were substances that could conduct electric current $(28.89 \%)$; electrolyte solution could conduct electric current because it contained free electrons which could conduct electricity (17.78\%); electrolytes were ionic compounds $(16.83 \%)$; if dissolved in water, ionic compounds would ionize into ions. The oxygen atom in water molecule interacted 
with anions and the hydrogen atom in water molecule interacted with the cation (37.78\%); Very polar covalent compounds dissolved in water ionized completely. The reaction equation was denoted two directions (14.3\%); a covalent compound which had low polarity when dissolved in water would ionize partially to produce few ions. The reaction equation was denoted one direction (18.73\%); Ionic compounds could conduct electricity only in solution form because they contained ions that could move freely $(13.65 \%) ; \mathrm{NaOH}$ solution could conduct electricity well because $\mathrm{NaOH}$ was classified as a strong electrolyte which ionized partially in solution (13.65\%); In the same molarity, $\mathrm{CH}_{3} \mathrm{COOH}$ produced less electrical conductivity compared to $\mathrm{KOH}$ because in water $\mathrm{CH}_{3} \mathrm{COOH}$ was ionized partially to produce few ions while $\mathrm{KOH}$ was ionized completely to produce many ions. The equation for the ionization reaction of $\mathrm{CH}_{3} \mathrm{COOH}$ was represented in two directions, while the equation for the ionization reaction of $\mathrm{KOH}$ was represented in one direction (32.28\%); $\mathrm{CH}_{3} \mathrm{COOH}$ was classified as non-electrolyte, which in its solution contained few ions $(17.78 \%)$. Some of the misconceptions revealed in this study confirmed the misconceptions that were revealed by previous researchers, there was Wiwi, Firman and Rofifah who used a similar type of instrument, there was a pictorial-based twotier multiple choices diagnostic test [19].

In general, each concept of electrolyte and non-electrolyte solutions, student misconceptions were identified in high, medium and low category schools. The most common student misconception in high and low category schools was the solvent was a solution component whose amount was always more than the solute, while the most common student misconception in medium category school was if dissolved in water, ionic compounds would ionize into ions. The oxygen atom in water molecule interacted with anions and the hydrogen atom in water molecule interacted with the cation.

The difference of student misconceptions in three schools could be identified by hypothesis test. Before hypothesis test, the normality and homogeneity tests were carried out. The results of the data normality test based on the Kolmogorov-Smirnov test, the significance level was more than 0.05 , there was 0.222 . This showed that the sample data was distributed normally. The results of the data homogeneity test based on the Lavence Test, the significance level was more than 0.05 , there was 0.075 . This showed that the data came from populations that had the same variance (homogeneous). The results of the one-way ANOVA test showed a significance level of less than 0.05 , there was 0.045 . This showed that there were significant differences misconceptions between students in high, medium and low category schools. The results of the Post Hoc Test showed that there were significant differences misconceptions between students in high category schools and low category schools.

Based on result of identification student misconceptions in high, medium and low category schools for each concept on electrolyte and non-electrolyte solution, the percentage of total students in high, medium and low category school who had misconceptions on electrolyte and non-electrolyte solution were shown Figure 1. 


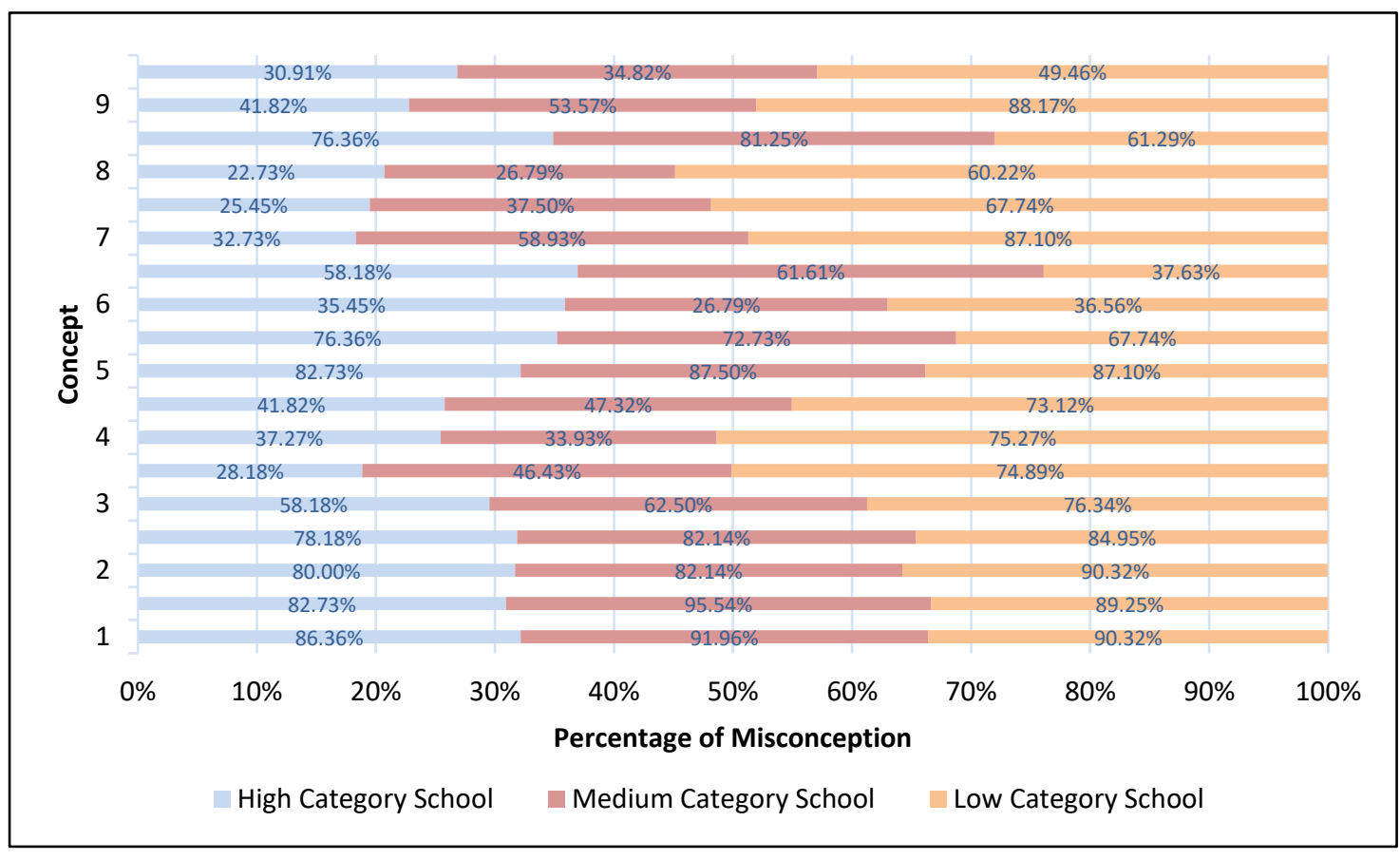

\begin{tabular}{|ll|}
\hline Note: & \\
1: Solvent & 5: Dissociation of lonic Compound \\
2: Solute & 6: Ionization of Covalent Compound \\
3: Electrolyte & 7: Conductivity of lonic Compound \\
4: Chemical Bond Type of Electrolyte Compound & 8: Electrical Conductivity Electrolyte \\
& 9: Nonelectrolyte \\
\hline
\end{tabular}

Figure 1. Percentage of total student misconceptions in high, medium and low category school

Theoretically, misconceptions were an obstacle for students in learning science [2]. Therefore, students with low learning achievement tended to have a high percentage of misconceptions and students with high learning achievement tended to have a low percentage of misconceptions. However, based on Figure 1, the student misconceptions in high, medium and low category schools for several concepts on electrolyte and non-electrolyte solution had a mismatch, there were misconceptions on types of chemical bonds of electrolyte compounds (question number 7), dissociation of ionic compounds (question number 10) and ionization of covalent compounds (question number 11) were more encountered in high category schools student than students in medium category schools, then misconceptions on electrical conductivity of electrolytes (question number 16), dissociation of ionic compounds (question number 10) and ionization of covalent compounds (question number 12) were more encountered in high category schools students than students in low category school and misconceptions on electrical conductivity of electrolytes (question number 16), dissociation of ionic compounds (question number 10), ionization of covalent compounds ( questions number 12) and solvents (questions number 1 and 2) were mostly encountered in medium category schools students compared to students in low category schools. 
The student misconceptions in high, medium and low category schools for several concepts on electrolyte and non-electrolyte solution had a mismatch indicates that the categorization of schools based on the National Examination of students could not reflect student achievement in these schools. Based on Mudjijanti's research, the national exam results obtained by students did not describe the students' real abilities because there were still many irregularities that occur during the implementation of exams in the field. Therefore, students with high national examination scores were not able to compete when they were at a higher level of education and their learning achievement was low. Misconception was an obstacle for students in learning, so that if students had misconceptions, their learning achievement would be low. Therefore, students with high average national examination scores did not necessarily have high learning achievement either, students in high or medium category schools had more misconceptions than students in low category schools [23].

The difference students' misconceptions for each concept could be identified by categorizing the difference percentage of total misconceptions. Students' misconceptions in high and medium category school were revealed that seventeen questions were categorized slightly different and one question was categorized different. Student misconceptions in high and low category school were revealed that ten questions were categorized slightly different, two questions were categorized different and six questions were categorized very different. Students' misconceptions in medium and low category schools revealed that one question was categorized no different, eight questions were categorized slightly different, eight questions were categorized different and one question was categorized very different. In general, there were significant differences for the total student misconceptions in three schools.

Based on the result of this study, in general, each concept of electrolyte and nonelectrolyte solutions, misconceptions were identified that were encountered by female and male students. The most common female and male student misconception was ionic compounds dissolved in water would ionize into ions. The oxygen atom in water molecule interacted with the anions and the hydrogen atom in water molecule interacted with the cation.

The difference between the misconceptions of male and female students could be identified by hypothesis test. Before hypothesis test, the normality and homogeneity tests were conducted first. The results of normality test based on the Shapiro-Wilk test, the significance level of data for female student misconceptions was more than 0.05 , there was 0.148 and the data significance level for male student misconceptions was more than 0,05 , there was 0.233 . This showed that the data was normally distributed. The results of homogeneity test were based on the Lavence Test, the significance level was more than 0.05 , there was 0.755 . This showed that data came from populations that had same variance (homogeneous). The t test results showed a significance level more than 0.05 , there was 0.755 . This showed that no significant 
difference misconceptions between male students and female students.

Based on the results of identification female and male student misconceptions for each concept on electrolyte and nonelectrolyte solution, the total percentage of female and male students who had misconceptions were showed in Figure 2. Based on Figure 2 in general there was no tendency for misconceptions of male students were more than female students or the misconception of female students were more than male students.

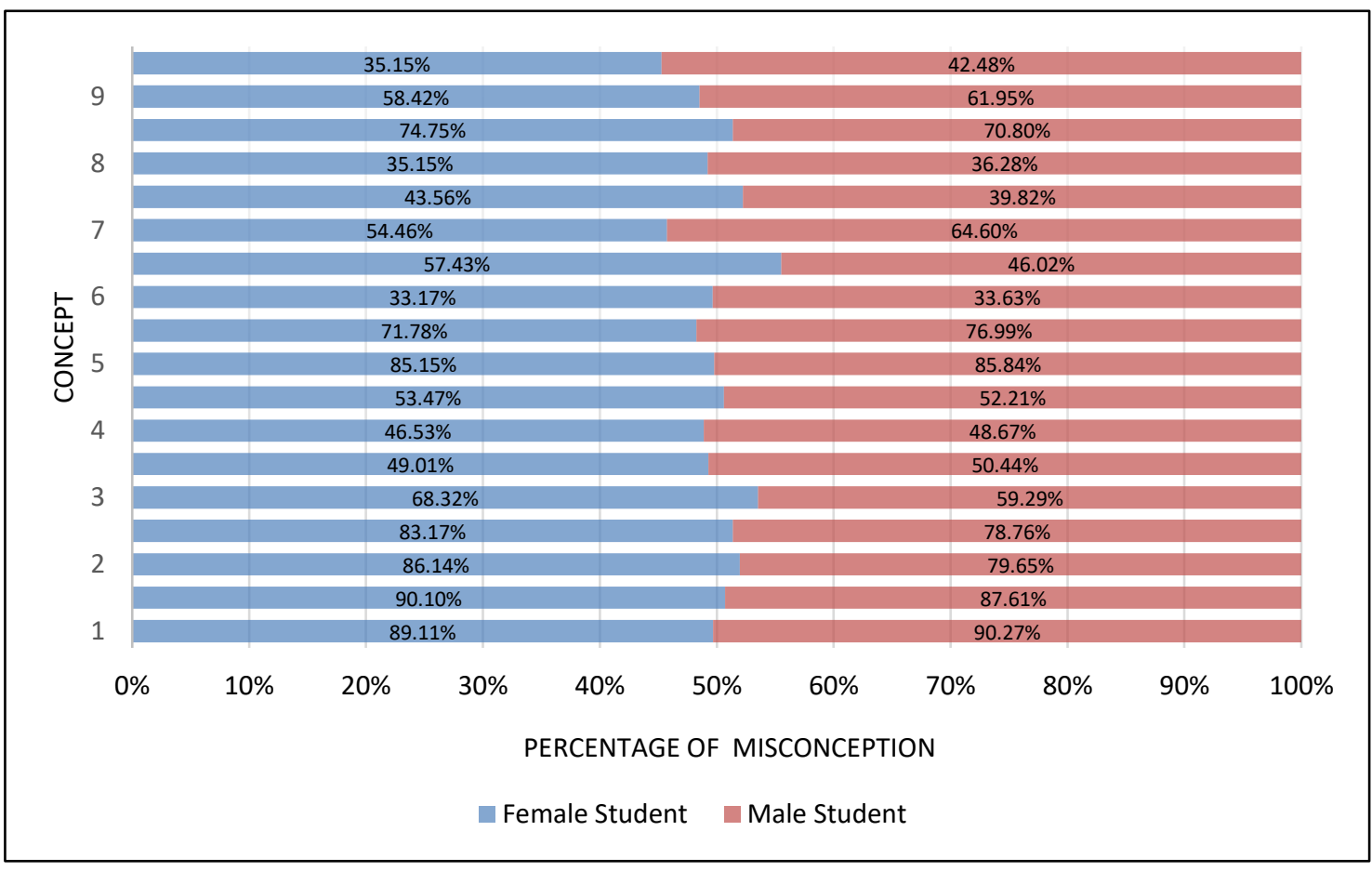

\section{Note:}

1: Solvent

2: Solute

3: Electrolyte

4: Chemical Bond Type of Electrolyte Compound
5: Dissociation of lonic Compound

6: Ionization of Covalent Compound

7: Conductivity of Ionic Compound

8: Electrical Conductivity Electrolyte

9: Nonelectrolyte

Figure 2. Percentage of total male and female student misconceptions

Misconceptions of male and female students revealed that two questions were categorized no different and sixteen questions were categorized slightly different. So that no significant difference misconceptions between female and male students because the difference total student misconceptions in each concept was generally slightly different.

Based on results of research, misconceptions of female and male students on electrolyte and non-electrolyte solution did not have a significant difference and there was no tendency for misconceptions of male students more than female students or misconceptions of female students more than male students. This was in accordance with results of research from several researchers said that gender was not a significant factor in determining student achievement in learning [25]. Inyang and Jegede, Shaw and 
Doan, Hannover and Kessel also said that gender had no effect on student achievement in science. Erinosho stated that the difference achievement in chemistry for boys and girls was not statistically significant [26]. Hyde showed that results of analysis consistently showed that gender differences did not have a significant effect on cognitive abilities. So, although cognitive ability was significantly and positively related to learning achievement, it could not explain that gender differences could affect learning achievement. Other factors that influenced learning achievement include genetic differences, attitudes; interest; talents and motivation of each individual, habits in developing children, impressions on special subjects, social environment, such as teachers, parents and friends [27].

\section{CONCLUSION}

The significant misconception encountered on class $X$ high school students in Kuningan about electrolyte and non-electrolytes solution identified 10 misconceptions. The misconceptions encountered on class $X$ high school students about electrolyte and non-electrolyte solution in high and low category schools in Kuningan had a significant difference, while the misconceptions encountered on female and male students on electrolyte and non-electrolyte solution had no significant difference. gender is not a significant factor in determining student success in learning.

\section{REFERENCES}

[1] J. H. Mc Millan, Classroom Assessment: Principles and Practice for Effective
Standard-Based Instruction. Boston, MA: Pearson Edition, 2007.

Google Scholar

[2] R. W. Dahar, Teori-Teori Belajar dan Pembelajaran. Penerbit Erlangga, Jakarta, 2006.

Google Scholar

[3] J. M. Nyachwaya, A.R. Mohamed, G.H. Roehrig, N.B. Wood, A.L. Kern and J. L. Schneider, "The development of an Open-Ended Drawing Tool: An Alternative Diagnostic Tool for Assessing Students Understanding of the Particulate Nature of Matter", J. Chem. Educ. Res. Pract., vol. 12, pp. 121-132, 2011.

DOI: 10.1039/C1RP90017J

[4] I. Devetak, M. Urbancic, K. S. W. Grm, D. Krnel, S. A. Glazar, "Submicroscopic Representations as a Tool for Evaluating Students' Chemical Conceptions", Acta Chim. Slov, vol. 51, pp. 799-814, 2004.

Google Scholar

[5] W. A Mehrens, and I. J Lehmann, Measurement and Evaluation: An "Education and Psychology. New York: Holt, Rinehart and winston, Inc., 1973. Google Scholar

[6] S. O Adodo, "Effects of Two-Tier Multiple Choice Diagnostic Assessment Items on Student's Learning Outcome in Basic Science Technology (BST)", Academic Journal of Interdisciplinary Studies Published by MCSERCEMAS-Sapienza University of Rome, vol. 2, no. 2, pp. 201-210, 2013.

DOI: 10.5901/ajis.2013.v2n2p201

[7] D. F Treagust, "Diagnostic Assessment in Science as a Means to Improving Teaching, Learning and Retention", Science and Mathematics Education Centre, Curtin University of Technoogy, Australia, pp. 1-11, 2006. Google Scholar

[8] H. Tüysüz, "Development of Two-Tier Diagnostic Instrument and Assess Students' Understanding in Chemistry", Sci. Res. Essays, vol. 4, no. 6, pp. 626631, 2009.

Google Scholar 
[9] E. Adadan and F. Savasci, "An Analysis of 16-17 Years Old Students' Understanding of Solution Chemistry Concepts Using a Two-Tier Diagnostic Instrument", Inter. J. Sci. Edu., vol. 33, no. 4, pp. 513-544, 2012.

DOI: 10.1080/09500693.2011.636084

[10] K. C. D Tan, K. S. Taber, N. K. Goh, and L. S.Chia, , "The Ionization Energy Diagnostic Instrument: A Two-Tier Multiple Choice Instrument to Determine High School Students' Understanding of Ionisation Energy", Chem. Edu. Res. Pract., vol. 6, no. 4, pp. 180-197, 2005

DOI: 10.1039/B5RP90009C

[11] A. L. Chandrasegaran, D. F. Treagust, and M.Mocerino, "The Development of a Two-Tier Multiple-Choice Diagnostic Instrument for Evaluating Secondary School Students' Ability to Describe and Explain Chemical Reactions Using Multiple Levels of Representation", Chem. Edu. Res. Pract, vol. 8, no. 3, pp. 293-307, 2007.

DOI: 10.1039/B7RP90006F

[12] A. S. L Loh, "Exploring Students' Understanding of Electrochemical Cells Using an Enhanced Two - Tier Diagnostic Instrument", Res. Sci. Tech. Edu., vol. 32, no. 3, pp. 229250, 2014.

DOI: $10.1080 / 02635143.2014 .916669$

[13] K. C. D Tan, and D. F Treagust, "Evaluating Student's Understanding of Chemical Bonding", School Science Review, vol. 81, no. 294, pp.75 - 83, 1999.

Google Scholar

[14] P Kumpha, P Suwannoi, and D. F. Treagust, "Thai Grade 10 Conceptual Understanding of Chemical Bonding", Procedia :Social and Behavioral Science, vol. 143, pp. $657-662,2014$. DOI: 10.1016/j.sbspro.2014.07.458

[15] Z. Halakova, and M. Proksa, "Two Kinds of Conceptual Problems in Chemistry Teaching", J. Chem. Edu., vol. 84, no. 1, pp. 172 - 174, 2007. DOI: $10.1021 /$ ed084p172
[16] A Tavassoli, S. Jahandar, and M Khodabandehlou, "The Effect of Pictorial Contexts on Reading Comprehension of Iranian High School Students: A Comparison Between Prevs. During Reading Activities", Ind. J. Fund. App. Li. Sci., vol. 3, no. 3, pp. 553-56, 2013.

Google Scholar

[17] T. Noh, and L. C. Scharmann, "Instructional Influence of a MolecularLevel Pictorial Presentation of Matter on Students' Conceptions and ProblemSolving Ability", J. Res. Sci. Teach., vol. 34, no. 2, pp. 199-217, 1998.

DOI:10.1002/(SICI)10982736(199702)34:2<199::AIDTEA6>3.0.CO;2-O

[18] R. Hanson, "Identify Student's Alternative Concepts in Basic Chemical Bonding - A Case Study of Teacher Trainees in The University of Education, Winneba", Inter. J. Innova. Res. Develop, vol. 4, no. 1, pp. 115122, 2015.

Google Scholar

[19] W. Siswaningsih, H. Firman, and R. Rofifah, "Pengembangan Tes Diagnostik Two-Tier Berbasis Piktorial untuk Mengidentifikasi Miskonsepsi Siswa pada Materi Larutan Elektrolit dan Nonelektrolit", Jurnal Pengajaran MIPA, vol. 20, no. 2, pp. 144-149, 2015. Google Scholar

[20] W. Siswaningsih, H. Hernani, and T Rahmawati, "Profil Miskonsepsi Siswa Sma Pada Materi Hidrokarbon Menggunakan Tes Diagnostik Pilihan Ganda Dua Tingkat", Jurnal Penelitian Pendidikan Kimia: Kajian Hasil Penelitian Pendidikan Kimia, vol. 1, no. 2, pp. 200-206, 2014. Google Scholar

[21] I. Devetak, dan S. A Glazar, "The Influence of 16 years old Students' Gender, Mental Abilities and Motivation on Their Reading and Drawing Submicrorepresentations Achievements", Inter. J. Sci. Edu., vol. 32, no. 12, pp. 1561-1593, 2009.

DOI: 10.1080/09500690903150609 
[22] Artdej, T. Ratanaroutai, R.K. Coll and T. Thongpanchang, "Thai Grade 11 Students' Alternative Conceptions for Acid-Based Chemistry", Res. Sci. Tech. Edu., vol. 28, no. 2, pp. 167-183, 2011. DOI: 10.1080/02635141003748382

[23] Mudjijanti, "Pengaruh Tes Masuk Berdasarkan Nilai Ujian Nasional (UN) Terhadap Prestasi Belajar Siswa", J. FIP. UNIKA Widya Mandala, vol. 2, pp. 19-31, 2011.

Google Scholar

[24] A Imam, and G. P Singh, , "Influence of Gender and Familial Factor's on Mathematics Achievement of Secondary School Students", Inter. J. Hum. Soc. Sci. Stud., vol. 2, pp. 50-57, 2015.

Google Scholar
[25] F. A Adesoji, "Investigating Gender Difficulties and Misconceptions in Inorganic Chemistry at The Senior Secondary Level", Inter. J. Afri. Afri. America. Stud., vol. 7, no. 1, pp. 1-7. Google Scholar

[26] E. J Yezierski, and J. P. Birk, "Misconceptions About Particulate Nature of Matter Using Animations to Close the Gender Gap", Res. Sci. Edu., vol. 83, no. 6, pp. 954-960, 2006. DOI: 10.1021/ed083p954

[27] M. Weis, T. Heikamp, and G Trommsdorff, "Gender Differences in School Achievement: The Role of SelfRegulation", Department of Psychology University of Konstanz Germany, vol. 4, pp. 1-10, 2013.

DOI: 10.3389/fpsyg.2013.00442 